\title{
Biological Aspects and Life Table Parameters of Cheletogenes ornatus (Canestrini \& Fanzago) (Acari:Cheyletidae) when Fed on Different Types of Food
}

\author{
M. F. Hassan*; M. E. El-Naggar**; Amira E. Mesbah ${ }^{* *}$ and Rania A. El-Nahas ${ }^{* *}$ \\ ${ }^{*}$ Dept. of Zoology and Agric. Nematology, Fac. of Agric., Cairo Univ., Giza, Egypt \\ ${ }^{* *}$ Plant Protec. Res. Institute, Giza, Egypt.
}

\begin{abstract}
Cheletogenes ornatus (C\&F) developed and reproduced on three different types of food, crawlers of the scale insect, Hemberlisia lataniae (Signoret); immatures of Eutetranychus orientalis (Klein) and the acarid mite, Tyrophagus putrescentiae (Shrank) at $20 \& 25 \pm 2{ }^{\circ} \mathrm{C}$ and $65 \pm 5 \%$ R.H. Females had two nymphal stages; while males had only one. Predator was found for the first time in high numbers on aromatic and medicinal plants, (Jasmine) Lonicera japonica Thunb. (F: Caprifoliaceae) hiding under H. lataniae, scale insect and in low numbers with Fig fruit trees during study period. As temperature changed between 20 and $25^{\circ} \mathrm{C}$, the incubation and both male and female immature stages periods decreased. Temperature also decreased significantly on the adult female and male longevity. C. ornatus lived longer on crawlers of $\mathrm{H}$. lataniae than other tested foods. The development at $25^{\circ} \mathrm{C}$ was faster than at $20^{\circ} \mathrm{C}$ a Significant greatest number of deposited eggs by female was $96 \pm 2.97$ at $25^{\circ} \mathrm{C}$ when fed on H.latania scale insect crawlers; while it was 48 eggs/female at $20^{\circ} \mathrm{C}$ when fed on acarid mite. Life table parameters showed that, The mean generation time (T) and doubling time (DT) values decreased with temperature increase. The values of $r_{m} ; R_{0}$ and $\lambda$ increased with temperature increase. Also crawlers of scale insect was the favorable followed by phytophagous mites then acarid mite.
\end{abstract}

Key words: Cheletogenes ornatus, Biological aspects, Life table parameters, Hemberlisia lataniae, Eutetranychus orientalis, Tyrophagus putrescentiae.

\section{INTRODUCTION}

Members of the family Cheyletidae are worldwide in distribution and can be found on plants, in soil, litter and vertebrate nests feeding on mites and small insects, while few are considered as biological control agents,(Gerson et al., 2003).

Predatory mite control strategy may depend on the crop and conditions in the field, especially temperature and humidity. In this study, Hemberlisia lataniae, scale insect was found inhabiting lonicera japonica with high numbers and also $F$. carica, fig fruit, causing great damage to them. So, we tried to solve these problems without using pesticides to decrease harm to crops by using predator cheyletid mite to control pests attacking these important crops.

Here, we address key questions to better understand the biology of the cheyletidmite, Cheletogenes ornatus (C. \& F.) its reproduction, biological aspects and life table parameters as an important agent for controlling scale-insects, acarid mites and phytophagus mites which considered the most destructive pests attacking fruit ornamental, ,aromatic and medicinal plants. So, its life table parameters were investigated when feeding on mite and insect preys.

\section{MATERIALS AND METHODS}

Acarid mite, Tyrophagus putrescentiae found on Fig fruit trees during the period of study then taken for rearing on cages filled with a layer of mixture of
(Cement: Clay: Charcoal) with percent of $(7: 2: 1)$ filled on the bottom of cages to depth of $0.5 \mathrm{~cm}$.Its bottom was scratched by using a needle to make convexo-concaved areas used as shelters and was suitable sites for predator mite rearing and laying eggs, Zaher et al., 1981. Water drops was added when needed .For individual rearing, newly hatched larvae were transferred individually to anew rearing plastic cells. The experiment was investigated twice daily Biological aspects recorded daily. Immature of acarid mite were supplied to predator mite, Chelotogenes ornatus when needed.

The brown citrus mite, Eutetranychus orientalis (Klein) (F: Tetranychidae) found attack fig fruit trees, Ficuscarica during the period of study then reared at $25^{\circ} \mathrm{C}$ on fresh mulberry leaves and supplied immature stages to the predatory mite, $C$. ornatus when needed.

The crawlers of scale insects, Hemberlisia lataniae (Signoret) which infested Jasmine, Lonicera japonica (Thunb.) (F: Caprifoliaceae) in high numbers during the year of study and crawlers introduced for predators when needed.

Culture of the predatory mite: For the main culture, Predator mite reared at Acarology laboratory of Plant Protection Research institute-Sharkia-Egypt for three successive generations. Females of Cheyletid mites were found on Jasmine for the first time and transferred for rearing substrates. Gravid females left for about $24 \mathrm{~h}$ and their eggs were used for biological aspects. This experiment was repeated with all tested prey. Different biological aspects were 
daily recorded. Other necessary data dealing with the predator's biology, fecundity and other biological aspects were continuously recorded. Observations taken by using Video camera. Data were statistically analyzed by Anova-test to compare means(L.S.Dtest, where $\mathrm{P}>0.05$ ).To study the effect of different prey species at two different temperature 20 and 25 $\pm 2{ }^{\circ} \mathrm{C}$ and $65 \pm 5 \%$ R.H. and life-table-parameter of C. ornatus were followed the formula of Andrewartha and Birch (1948), and Basic computer program of Abou Setta et al. (1986).

\section{RESULTS AND DISCUSSION}

It is well known that members of the family Cheyletidae show a considerable variation in their feeding habits, including acarid, tetranychid and tenuipalpid mites, as well as scale insects, Carrillo $e t$ al., 2012.

C. ornatus observed in high numbers associated with phytophagous mites and scale insects infestation in Jasmine, Lonicera japonica, honey suckle during the period of study.

\section{The effect of food type and temperature on biological aspects}

Incubation period: Table, (1). Showed a noticeable effect on the embryonic development of $C$. ornatus (C. \& F.); incubation period was greatly affected in case of male and female on different tested foods. The shortest incubation period was (2.5, 2.25 and 2.1 days) for predator males but for predator females it was (3.7, 3.28 and 2.6 days) at $25^{\circ} \mathrm{C}$; while the longest incubation periods recorded were(5.65, 5.4 and 4.9 days) for males but for females were $(7.3,6.45$ and 5.45 days) at $20^{\circ} \mathrm{C}$, in case of feeding on crawlers of the scale insect, $H$. lataniae, immatures of the citrus brown mite $E$. orientalis and the acarid mite, $T$. putrescentiae, respectively. Predators total immature followed similar trend.

Adult longevity of the cheyletid predator mite, $C$. ornatus was highly influenced by the food employed. Feeding on crawlers of $H$. lataniae gave longest life cycle, adult longevity and life span; while feeding on immatures of the acarid mite, resulted in the shortest periods.

Fecundity was significantly affected by temperature. Predator female fecundity, at $25^{\circ} \mathrm{C}$ was the most suitable. Crawlers of $H$. lataniascale insect proved to be the most favorable food as it gave the highest reproduction rate $(96.2 \&$ 67eggs) then, immatures of $E$. orientalis ( $86 \&$ 53eggs ); while feeding in immatures of the acarid mite, resulted in the lowest number of deposited eggs (74 \& 48 eggs) at 20 and $25^{\circ} \mathrm{C}$, respectively.
Life table parameters (Table 3). Life table parameters showed that, the mean generation time (T) and doubling time (DT) values decreased with temperature increase, thus the reproduction of mite increased at $25^{\circ} \mathrm{C}$ than at $20^{\circ} \mathrm{C}$. In addition, the values of $\mathrm{r}_{\mathrm{m}} ; \mathrm{R}_{\mathrm{o}}$ and $\lambda$ increased with temperature increase.This mite favored high temperature. Also crawlers of the scale insect was the favorable followed by phytophagous mites then acarid mites.

Predation capacity The male and female of the predatory mite, $C$. ornatus have a high predation capacity when fed on crawlers of scale insect; immatures of tetranychid mite and immatures of acarid mite, respectively (Table, 4). The number of consumed prey individuals was differed according to type of food and stage of introduced prey. The predator predation potential was greater when fed on crawlers of scale insect, $H$. lataniae. Mesbah and omar (2014) showed that eggs of $R$. indica was the most preferable food for larva and all stages of predator mite, $C$. ornatus compared with immatures of $R$. indica and crawlers of date scale insect.

At $20^{\circ} \mathrm{C}$, food consumption during its immature stages averaged (68.2; $53 \& 36.7)$ prey and (44.5; $37.2 \& 26.4$ ) individuals prey for female and male when fed on the crawlers of scale insect, immatures of each of tetranychid and acarid mite, respectively; while, during adult longevity were $(166,152.6$ and $90.8)$ and $(146 ; 129$ and 74.8$)$ for the same preys, respectively and during its life span it averaged (234.2, 205 and 127.5) prey individuals and (189, 176.8 and 97.4) for females and males when fed on the crawlers of the scale insect, immatures of the tetranychid and acarid mite, respectively. At $25^{\circ} \mathrm{C}$, prey consumption during predator immature stages averaged $41 ; 34 \& 23.2$ and $34.2 ; 27 \& 18.2$ preys for female and male for the same preys mentioned before, respectively; while, during adult longevity were $152.4 ; 141 \& 83$ prey and $137 ; 114 \& 68$ of the same prey, respectively and during its life span it averaged 216; $193 \& 121.2$ prey for females and for males consumed $180 ; 148.3 \& 92$ prey for the same preys, respectively. This agreed with Wafa, et al., 1970 who reported that the adult female and male of Eutogenes africanus Wafa \& Soliman consumed an average of 186 and 156 eggs of $P$. olae, respectively. The life cycle averaged 31 days and the deposited eggs per female were 16 eggs at $29^{\circ} \mathrm{C}$. Zaher and Soliman, (1972) observed that $C$. ornatus occured widely throughout Egypt on fruit trees and ornamental plants and played an important role in the control scale insects; females laid an average of 16.8 eggs each, the oviposition period averaged 12.8. Zaher et al. (1982) observed that the effect of food type on the development, feeding capacity and fecundity of Cheletogenes ornatus (C. \& F.), a predator of scale 
Table (1): Duration in days of developmental stages of C. ornatus fed on three different preys at 20 and $25 \pm$ $2{ }^{\circ} \mathrm{C}$ and $65 \pm 5 \% \mathrm{R}$. H.

\begin{tabular}{|c|c|c|c|c|c|c|c|}
\hline \multirow{3}{*}{ C. ornatus } & \multirow{3}{*}{ Sex } & \multicolumn{3}{|c|}{$20^{\circ} \mathrm{C}$} & \multicolumn{3}{|c|}{$25^{\circ} \mathrm{C}$} \\
\hline & & \multirow{2}{*}{$\begin{array}{l}\text { Crawlers of } \\
\text { scale insect }\end{array}$} & \multicolumn{2}{|c|}{ Mites immatures } & \multirow{2}{*}{$\begin{array}{c}\begin{array}{c}\text { Crawlers of scale } \\
\text { insect }\end{array} \\
\text { H. lataniae }\end{array}$} & \multicolumn{2}{|c|}{ Mites immatures } \\
\hline & & & E. orientalis & T. putrescentiae & & E. orientalis & T. putrescentiae \\
\hline \multirow{2}{*}{ Egg } & 9 & $7.3^{a} \pm 0.42$ & $6.45^{b} \pm 0.75$ & $5.45^{\mathrm{c}} \pm 0.59$ & $3.7^{a} \pm 0.45$ & $3.28^{b} \pm 0.27$ & $2.6^{\mathrm{c}} \pm 0.35$ \\
\hline & $\sigma^{x}$ & $5.65^{a} \pm 0.36$ & $5.4^{\mathrm{a}} \pm 0.37$ & $4.9^{b} \pm 0.32$ & $2.5^{\mathrm{a}} \pm 0.35$ & $2.25^{b} \pm 0.31$ & $2.1^{b} \pm 0.29$ \\
\hline \multirow{2}{*}{ A. Larva } & $q$ & $6.1^{a} \pm 0.52$ & $5.63^{b} \pm 0.53$ & $5.53^{b} \pm 0.38$ & $5.58^{a} \pm 0.62$ & $4.63^{b} \pm 0.52$ & $3.95^{c} \pm 0.54$ \\
\hline & $0^{x}$ & $5.75^{a} \pm 0.38$ & $5.25^{b} \pm 0.33$ & $4.2^{b} \pm 0.33$ & $5.45^{\mathrm{a}} \pm 0.37$ & $5.1^{b} \pm 0.46$ & $3.78^{b} \pm 0.28$ \\
\hline \multirow{2}{*}{ Q. Larva } & 웅 & $1.7 \pm 0.48$ & $1.48 \pm 0.39$ & $1.35 \pm 0.32$ & $1.5 \pm 0.42$ & $1.33 \pm 0.29$ & $1.25 \pm 0.25$ \\
\hline & $0^{x}$ & $1.5 \pm 0.42$ & $1.35 \pm 0.32$ & $1.25 \pm 0.25$ & $1.35 \pm 0.32$ & $1.25 \pm 0.25$ & $1.0 \pm 0.2$ \\
\hline \multirow{2}{*}{ A. Protonymph } & 웅 & $5.81^{\mathrm{a}} \pm 0.43$ & $4.21^{b} \pm 0.49$ & $4.18^{b} \pm 0.50$ & $5.28^{a} \pm 0.32$ & $3.78^{b} \pm 0.28$ & $3.10^{c} \pm 0.58$ \\
\hline & $\sigma^{2}$ & $7.5^{a} \pm 0.57$ & $6.75^{b} \pm 0.69$ & $5.6^{\mathrm{a}} \pm 0.39$ & $6.3^{\mathrm{a}} \pm 0.42$ & $5.78^{b} \pm 0.76$ & $4.93^{c} \pm 0.31$ \\
\hline \multirow{2}{*}{ Q. Protonymph } & 웅 & $1.23 \pm 0.24$ & $1.1 \pm 0.21$ & $0.88 \pm 0.17$ & $1.35 \pm 0.32$ & $1.2 \pm 0.22$ & $0.9 \pm 0.19$ \\
\hline & $\sigma^{7}$ & $1.1 \pm 0.21$ & $0.95 \pm 0.19$ & $0.68 \pm 0.16$ & $0.88 \pm 0.18$ & $0.75 \pm 0.18$ & $0.59 \pm 0.14$ \\
\hline A. Deutonymph & \% & $5.88^{a} \pm 0.49$ & $5.62^{a} \pm 0.54$ & $4.13^{b} \pm 0.61$ & $5.48^{a} \pm 0.59$ & $4.2^{b} \pm 0.40$ & $3.28^{c} \pm 0.49$ \\
\hline Q. Deutonymph & 우 & $1.58 \pm 0.49$ & $1.39 \pm 0.39$ & $1.28 \pm 0.28$ & $1.45 \pm 0.46$ & $1.33 \pm 0.3$ & $1.1 \pm 0.21$ \\
\hline \multirow{2}{*}{ Total immature } & 웅 & $22.30^{\mathrm{a}} \pm 0.75$ & $19.34^{b} \pm 0.95$ & $17.35^{\mathrm{c}} \pm 0.96$ & $20.64^{a} \pm 0.97$ & $18.2^{\mathrm{b}} \pm 0.89$ & $13.58^{\circ} \pm 1.28$ \\
\hline & $0^{x}$ & $15.85^{\mathrm{a}} \pm 0.97$ & $14.27^{b} \pm 1.1$ & $11.73^{b} \pm 0.51$ & $13.98^{a} \pm 0.55$ & $12.88^{\mathrm{b}} \pm 0.78$ & $10.30^{\mathrm{c}} \pm 0.52$ \\
\hline \multirow{2}{*}{ Life cycle } & 9 & $29.60^{a} \pm 0.77$ & $25.88^{b} \pm 1.19$ & $22.7^{c} \pm 1.4$ & $24.34^{a} \pm 1.36$ & $21.30^{\mathrm{b}} \pm 0.69$ & $16.18^{c} \pm 1.35$ \\
\hline & $0^{n}$ & $21.50^{\mathrm{a}} \pm 1.01$ & $19.67^{b} \pm 1.27$ & $16 . .63^{c} \pm 0.56$ & $16.48^{\mathrm{a}} \pm 0.64$ & $15.13^{\mathrm{b}} \pm 0.96$ & $12.4^{\mathrm{c}} \pm 0.66$ \\
\hline \multirow{2}{*}{ Adult longevity } & 9 & $40.53^{\mathrm{a}} \pm 1.14$ & $37.7^{b} \pm 2.02$ & $35.08^{c} \pm 0.96$ & $37.38^{\mathrm{a}} \pm 1.18$ & $31.15^{b} \pm 1.32$ & $26.18^{c} \pm 1.01$ \\
\hline & 0 & $35.2^{a} \pm 1.62$ & $33.3^{\mathrm{bb}} \pm 1.10$ & $30.5^{\mathrm{c}} \pm 1.08$ & $33.7^{\mathrm{a}} \pm 1.34$ & $29.1^{b} \pm 1.78$ & $22.9^{c} \pm 1.19$ \\
\hline \multirow{2}{*}{ Life span } & 9 & $70.13^{a} \pm 1.36$ & $63.58^{b} \pm 2.53$ & $57.88^{c} \pm 1.8$ & $61.72^{a} \pm 1.83$ & $50.9^{b} \pm 1.69$ & $42.36^{c} \pm 1.76$ \\
\hline & $0^{x}$ & $56.70^{\mathrm{a}} \pm 1.11$ & $52.97^{b} \pm 1.12$ & $47.13^{\mathrm{c}} \pm 1.09$ & $50.18^{a} \pm 1.53$ & $44.23^{b} \pm 2.1$ & $35.3^{\mathrm{c}} \pm 1.49$ \\
\hline
\end{tabular}

A. $=$ Active, $\mathrm{Q} .=$ Quiescent

Table (2): Effect of different preys on duration of pre -oviposition ,oviposition , post-oviposition , fecundity and daily rate of C. ornatus (C.\&F.) females at 20 and $25 \pm 2{ }^{\circ} \mathrm{C}$ and $65 \pm 5 \%$ R.H.

\begin{tabular}{|c|c|c|c|c|c|c|c|c|}
\hline \multirow{3}{*}{ Prey type } & \multicolumn{4}{|c|}{$20^{\circ} \mathrm{C}$} & \multicolumn{4}{|c|}{$25^{\circ} \mathrm{C}$} \\
\hline & \multicolumn{3}{|c|}{ Duration (in days) } & \multirow{2}{*}{$\begin{array}{c}\text { Fecundity\& } \\
\text { Daily rate }\end{array}$} & \multicolumn{3}{|c|}{ Duration in days } & \multirow{2}{*}{$\begin{array}{c}\text { Fecundity \& } \\
\text { Daily rate }\end{array}$} \\
\hline & $\begin{array}{l}\text { Pre- } \\
\text { oviposition }\end{array}$ & Oviposition & $\begin{array}{l}\text { Post- } \\
\text { oviposition }\end{array}$ & & $\begin{array}{c}\text { Pre- } \\
\text { oviposition }\end{array}$ & Oviposition & $\begin{array}{c}\text { Post- } \\
\text { oviposition }\end{array}$ & \\
\hline H. lataniae & $5.88^{a} \pm 0.34$ & $25.5^{\mathrm{a}} \pm 1.14$ & $9.15^{b} \pm 0.53$ & $\begin{array}{c}67^{\mathrm{a}} \pm 1.72 \\
\&(2.63) \\
\end{array}$ & $5.45^{a} \pm 0.44$ & $23^{a} \pm 0.82$ & $8.93^{a} \pm 0.69$ & $\begin{array}{c}96^{\mathrm{a}} \pm 2.97 \\
\&(4.17) \\
\end{array}$ \\
\hline E. orientalis & $5.6^{b} \pm 0.37$ & $23.5^{b} \pm 0.71$ & $8.9^{\mathrm{c}} \pm 0.74$ & $\begin{array}{c}53^{\mathrm{b}} \pm 3.74 \\
\&(2.26) \\
\end{array}$ & $4.45^{b} \pm 0.76$ & $21.8^{b} \pm 0.63$ & $4.9^{b} \pm 0.74$ & $\begin{array}{c}86^{\mathrm{b}} \pm 5.91 \\
\&(3.94) \\
\end{array}$ \\
\hline T. putrescentiae & $3.43^{\mathrm{c}} \pm 0.37$ & $22.2^{\mathrm{c}} \pm 1.32$ & $8.15^{\mathrm{c}} \pm 0.74$ & $\begin{array}{c}48^{c} \pm 1.26 \\
\&(2.16)\end{array}$ & $2.88^{c} \pm 0.32$ & $19.6^{c} \pm 1.27$ & $3.7^{c} \pm 0.72$ & $\begin{array}{c}74^{\mathrm{c}} \pm 4.68 \\
\&(3.78) \\
\end{array}$ \\
\hline L.S.D & 0.387 & 0.994 & 0.679 & 2.281 & 0.495 & 0.865 & 0.655 & 4.291 \\
\hline
\end{tabular}

Table (3): Life table parameters of C. ornatus (C. \& F.) females fed on three different types foods in laboratory at 20 and $25 \pm 2{ }^{\circ} \mathrm{C}$ and $65 \pm 5 \%$ R.H.

\begin{tabular}{lccc|cccc}
\hline & \multicolumn{3}{c}{$20^{\circ} \mathrm{C}$} & \multicolumn{3}{c}{$25^{\circ} \mathrm{C}$} \\
\cline { 2 - 9 } & H. lataniae & E. orientalis & T. putrescentiae & H. lataniae & E. orientalis & T. putrescentiae \\
\hline Mean generation time (Tc) a & 34.3 & 28.74 & 26.84 & 27.35 & 23.04 & 19.04 \\
\hline Doubling time (DT) a & 6.98 & 6.24 & 5.98 & 5.06 & 4.45 & 3.77 \\
\hline Net reproductive rate $(\mathrm{Ro}) \mathrm{b}$ & 30.11 & 24.26 & 22.32 & 42.26 & 36.27 & 33.44 \\
\hline Intrinsic rate of increase $(\mathrm{rm}) \mathrm{c}$ & 0.099 & 0.111 & 0.116 & 0.137 & 0.156 & 0.184 \\
\hline Finite rate of increase $(\lambda)$ & 1.104 & 1.117 & 1.123 & 1.147 & 1.169 & 1.202 \\
\hline Gross reproduction rate $(\mathrm{GRR})$ & 36.41 & 34.19 & 32.96 & 50.1 & 53.07 & 45.99 \\
\hline
\end{tabular}


Table (4): Food consumption and daily rate of predatory mite, C. ornatus fed on three different types of food at $20 \& 25^{\circ} \mathrm{C}$ and $65 \%$ R.H.

\begin{tabular}{|c|c|c|c|c|c|c|c|c|c|c|c|c|c|}
\hline \multirow{5}{*}{$\begin{array}{l}\text { Parameter } \\
\text { prey } \\
\text { species }\end{array}$} & \multirow{5}{*}{ Sex } & \multicolumn{12}{|c|}{ No. of devoured prey individuals } \\
\hline & & \multicolumn{6}{|c|}{$20^{\circ} \mathrm{C}$} & \multicolumn{6}{|c|}{$25^{\circ} \mathrm{C}$} \\
\hline & & \multirow{2}{*}{\multicolumn{2}{|c|}{$\begin{array}{l}\text { Crawlers of } \\
\text { scale insect } \\
\text { H. lataniae }\end{array}$}} & \multicolumn{4}{|c|}{ Immatures } & \multicolumn{2}{|c|}{$\begin{array}{l}\text { Crawlers of } \\
\text { scale insect }\end{array}$} & \multicolumn{4}{|c|}{ Immatures } \\
\hline & & & & \multicolumn{2}{|c|}{ E. orientalis } & \multicolumn{2}{|c|}{$\begin{array}{c}T . \\
\text { putrescentiae }\end{array}$} & \multicolumn{2}{|c|}{ H. lataniae } & \multicolumn{2}{|c|}{$\begin{array}{c}E . \\
\text { orientalis }\end{array}$} & \multicolumn{2}{|c|}{$\begin{array}{c}T . \\
\text { putrescentiae }\end{array}$} \\
\hline & & $\mathrm{T}$ & $\mathrm{Da}$. & $\mathrm{T}$ & Da. & $\mathrm{T}$ & Da. & T. & $\mathrm{Da}$. & T. & Da. & $\mathrm{T}$ & $\mathrm{Da}$. \\
\hline \multirow{2}{*}{$\begin{array}{l}\text { Total } \\
\text { immatures }\end{array}$} & $\sigma^{2}$ & 44.5 & 3.36 & 37.2 & 3.1 & 26.4 & 2.69 & 43 & 3.66 & 34.3 & 3.15 & 24 & 2.76 \\
\hline & 9 & 68.2 & 3.83 & 53 & 3.43 & 36.7 & 2.65 & 63.6 & 3.89 & 52 & 4.12 & 38.2 & 3.69 \\
\hline \multirow{2}{*}{ Longevity } & $\sigma^{*}$ & 146 & 4.15 & 129 & 3.87 & 74.8 & 2.45 & 137 & 4.1 & 114 & 3.9 & 68 & 2.97 \\
\hline & q & 166 & 4.1 & 152.6 & 4.05 & 90.4 & 2.58 & 152.4 & 4.1 & 141 & 4.53 & 83 & 3.17 \\
\hline \multirow{2}{*}{ Life- Span } & $\sigma^{x}$ & 190.5 & 3.03 & 166.2 & 2.89 & 101.2 & 1.96 & 180 & 3.59 & 148.3 & 3.35 & 92 & 2.61 \\
\hline & 9 & 234.2 & 3.34 & 205 & 3.22 & 127.1 & 2.2 & 216 & 3.49 & 193 & 3.84 & 121.2 & 2.82 \\
\hline
\end{tabular}

$\mathrm{T} .=$ Total rate $\quad$ Da.= Daily date

insects and phytophagous mites, was investigated in the laboratory at $28{ }^{\circ} \mathrm{C}$ and $80 \%$ R.H. Individuals reared on eggs and immatures of the scale insects Parlatoria oleae (Colv.) and Chrysomphalus ficus (L.) and of the mites Tetramynychus urticae Koch and Cenopalpus pulcher (C. \& F.), the female had two nymphal stages and the male had one. Development was more rapid, adult longevity and oviposition period were longer, and fecundity greater in predators fed on eggs, especially those of Tetranychus and Cenopalpus. Male predators usually emerged as adults before the females. C. ornatus attacked greater numbers of prey mites than of scale insects and laid more eggs when reared on mites. The most suitable and preferred prey was Cenopalpus pulcher, followed by $T$. urticae, $P$. oleae and C. ficus in order of preference. Moraes et al. (1989) reported biology $C$. ornatus, the most common predator of Pinnaspis aspidistrae (Signoret) in Brazil. At $28 \pm 2^{\circ} \mathrm{C}$ the duration of its life cycle was 40.6 and 31 days for males and females respectively and durations of female immature stages slightly shorter than mentioned by Zaher et al. (1981).

\section{REFERENCES}

Abou-Setta, M. M.; Sorrell, R.W. and Childers, C.C. 1986.Life 48: A BASIC computer program to calculate life table parameters for an insect or mite species. Florida Entomologist, 69(4): 690-697.

Andrewartha, H.G. and Birch, L.C. 1954. The distribution and abundance of animals. Univ. of Chicago Press, USA.
Carrillo, D; Frank, J. H; Rodrigues, J. C and Pena, J. A. 2012. A review of the natural enemies of the red palm mite, Raoiella indica (Acari: Tenuipalpidae). Experimental and Applied Acarology, 57: 347-360.

Gerson, U.; Smiley, R. L. and Ochoa, R. 2003. Mites (Acari) for pest control. Oxford, Blackwell Science, 539p.

Mesbah, A. E. and Omar, N.A. 2014. Predator-prey preferences and Life-Table-Parameters of Cheletogenes ornatus (Canestrini \& Fanzago) to red palm mite Raoiella indica Hirst and datescale-insect Parlatoria blanchardii (Targ.) (Acari: Cheyletidae: Tenuipalpidae). Journal of Egyptian Society of Acarology,(8)2.

Moraes, G. J. D; Neto, R. S. and Pinto, H. C. S. 1989. Morphology, biology and pesticide tolerance of Chelotogenes ornatus [Acari: Cheyletidae]. 34(4): 477-484.

Wafa, A. K.; Zaher, M. A. and Soliman, Z. R. 1970. Life-history of the predator mite Eutogenes africanus Wafa and Soliman (Acarina: Cheyletidae). Bull. Soc. Ent. d'Egypte 54: $129-131$.

Zaher, M. A. and Z. R. Soliman. 1972. Life-history of the predator mite, Cheletogenes ornatus (Canestrini and Fanzago). Bull. Soc. Ent. Egypt, 55: 85-9.

Zaher, M. A.; Yousef, A. E. A. and Kandil, M. M. 1982. Effect of food on the biology ofCheletogenesornatus (C. \& F.) [Acari: Prostigmata: Cheyletidae]. Acarologia, 22(4): 361-366. 